\title{
Educational Technology of Virtual Physics Laboratory (VPL) for the Microscopic Concept
}

\author{
Firmanul Catur Wibowo ${ }^{1,2, *}$, Agus Setiawan², Ubed Alizkan², Dina Rahmi Darman², Esmar Budi ${ }^{1}$ \\ ${ }^{1}$ Department of Physics Education, Universitas Negeri Jakarta, Indonesia \\ ${ }^{2}$ Department of Physics Education, Universitas Sultan Ageng Tirtayasa, Indonesia \\ ${ }^{3}$ Department of Mechanical Engineer Education, Universitas Pendidikan Indonesian, Indonesia
}

Received October 9, 2019; Revised November 19, 2019; Accepted November 25, 2019

Copyright $\odot 2019$ by authors, all rights reserved. Authors agree that this article remains permanently open access under the terms of the Creative Commons Attribution License 4.0 International License

\begin{abstract}
The research aims to educational technology for microscopic concept of virtual physics laboratory (VPL) on the concept of heat transfer. Heat transfer is one of the concepts in physics that is often considered difficult by students because it contains abstract and microscopic concepts. This is exacerbated by not conducting experimental activities, therefore the media is needed in the form of virtual labs that can visualize the process of heat transfer microscopically. This research method is research and development using Phases of the 4-D model which includes 4 Phases: defining, design, developing and disseminating. VPL media that has gone through the Phases of validation and revision, then through the testing phase is limited to 60 students. The results of VPL media expert obtained an average value of $87,50 \%$ with a very good category, results of VPL content expert obtained an average value of $84.44 \%$ with a very good category, and the results of Test were limited to students obtaining an average score of $86 \%$ with a very good category. It can be concluded that the learning media developed in the form of VPL can visualize the process of microscopic heat transfer that can be used in physics learning.
\end{abstract}

Keywords Educational Technology, Learning Media, Virtual Physics Laboratory (VPL), Microscopic Concept

\section{Introduction}

Science is born from the observation of a natural phenomenon which is studied continuously and systematically so that a concept of science is obtained. Science can be claimed as scientific knowledge, that is, a science that has been tested for truth through systematic or scientific methods [3]. Physics is one branch of Science specifically studying physical phenomena that occur in the universe both macroscopic and microscopic [10]. If microscopic phenomena can be understood, the macroscopic phenomenon can also be easily understood [19]. Physics learning has been trapped in method routines that are formulaic and problem solving, so the learning process, especially physics subjects in schools, has not produced the results as expected [17].

The process of learning physics should be a learning process that involves complex student activities. In each study, efforts must be made to deliver students to the mastery of the competencies proclaimed. In the minimum learning process there are two very important elements, namely the learning model and learning media, where both aspects are interrelated [14]. Learning media becomes a tool that can be used to visualize abstract concepts, so students can more easily understand the concepts being taught. The use of instructional media by teachers in learning activities becomes an important part that must be prepared carefully and planned in teaching and learning activities.

The use of appropriate learning media can facilitate students in understanding abstract concepts as a whole. The concept of physics that is considered difficult is one of them is the transfer of heat. This concept is difficult to understand because it cannot be observed directly by students. This is in accordance with the results of the study "Characteristic of physics consists of microscopic properties and macroscopic. Physics is defined as a concept that can be observed with the eye and measured [18]. Heat transfer contains concepts that are difficult to observe directly by students so that the use of learning media in learning activities has an important role as a teacher's aide in explaining the concept of heat transfer. The results of a preliminary study conducted by researchers in several teacher in senior high schools in Indonesia with the method of interviewing several physics teachers showed that in general the availability of learning media was still very 
lacking and needed in physics learning. Based on the preliminary study that has been carried out, it can be concluded that the need for a learning media in learning physics, especially in microscopic concepts. Therefore, given the importance of the function and role of learning media as a means of teachers in the learning process, the need for the development of learning media that can visualize microscopic concepts. The development of various visualization media of physical phenomena that are abstract and microscopic until now has been carried out for the benefit of the social learning process, including e.g.: optical simulation [2]; simulation of electricity and magnetism [8]; virtual laboratory simulation of core physics [12]; virtual laboratory simulation about science learning [7]; virtual laboratory simulation of electric circuit [15]; virtual laboratory simulation of modern physics [6]; Virtual simulation of thermal expansion [19]; heat transfer simulation [20]; virtual laboratory simulation [9]; simulation of battery dry cell [18].

Based on the research that has been done before by the researchers it can be concluded that the development of learning media in physics learning has been widely carried out especially on microscopic concept [4]. Until now, learning media in the form of simulations developed mostly not yet virtual labs are still limited to ordinary simulations which visualize microscopic physical phenomena [23] but, not yet facilitated for model manipulation. As for the learning media on the concept of heat transfer, the development is only limited to ordinary simulation media, not yet virtualized. Therefore, the need for the development of learning media that can visualize concepts or physical phenomena concerns heat transfer by conduction, convection and radiation at the microscopic level.

\section{Virtual Laboratory (VL)}

Virtual Laboratory is one of the multimedia learning formats categorized into simulation and experiment or experimental groups. The simulation format is a format that tries to match the dynamic processes that occur in the real world, for example to simulate flying plane, where the user seems to be doing activities flying an airplane, running a small business, or controlling a nuclear power plant [15]. Basically this format tries to provide experience of real-world problems that are usually associated with a risk. The format of experiments or experiments is similar to simulations, but is more aimed at practical activities in science, biology, chemistry and physics laboratories [22]. The program provides a series of tools and concepts, then users can conduct experiments or experiments according to instructions and then be able to develop other experiments based on these instructions. It is expected that in the end the user can explain a particular concept or phenomenon based on the experiments they have done in a VL [5]. VL can be used to transfer both conceptual and procedural knowledge. VL can be used to overcome the limited tools and chemicals for lab work, can provide a visualization of how the laboratory is done.

Based on some experts' opinions, it can be concluded that VL as a product of computer-based learning media and technology innovation can be applied in schools with information technology in the 'learning process. VL are cheaper, safer and suitable for use by students who have a visual learning style because students can explore VL according to their speed and needs. VL is very useful as a medium for teaching safe and inexpensive.

Functions and Uses of VL can be used to support a practicum system that runs conventionally and also provides a visualization of how the practicum is carried out, as good as overcoming obstacles that make practicum difficult to do, so that chemical experiments that cannot be carried out in a real laboratory because the limitations of tools and concept like real to do with a VL. By using a virtual lab, students can freely explore knowledge through replacing various parameters contained in the 3 simulation practices, so that analysis can be obtained without having to use instruments and chemicals that are dangerous and expensive. Virtual labs or simulation laboratories have been used for two purposes in chemical education. First, virtual labs are used to provide and show visual representations of chemistry concepts to students and the second virtual laboratory is used to provide students with readiness in laboratory activities [16]. The advantages of Virtual laboratory in learning at school are familiar. A lot of learning in schools is not possible for practicum activities because certain reasons use virtual labs to assist in mastering concepts. The use of virtual labs is still carried out of course because the VL has advantages [7] suggested that the advantages of virtual labs are as follows:

a. Improve creative thinking skills and scientific problem solving.

b. Develop skills in the ICT field without ignoring laboratory knowledge.

c. You don't have to bring in actual practical equipment, which sometimes doesn't make it affordable.

d. Practicum can be done anywhere and anytime.

e. Safety, with learning using a virtual laboratory of student safety is guaranteed because it does not experiment directly. This is beneficial if research is carried out with hazardous substances.

f. Can expand student experience, because it provides an opportunity to explore places in the world that are impossible in the real world. For example nuclear production, explosive mountain processes, and life in space.

g. The opportunity to investigate, provides the opportunity for students to experiment with simulations in the surrounding environment. 
The one of the advantages of using a VL is the visualization at the microscopic [1]. The submicroscopic visualization of the virtual laboratory can be used as an alternative learning because traditional teaching is not enough to attract students' interest and is considered boring. Based on the advantages expressed by the experts, it can be seen that the virtual laboratory use in learning can be done if practical laboratory activities in the laboratory are not possible. The following is an analysis of the availability of virtual laboratory simulation media on the heat transfer material that has been developed [21].

Table 1. Analysis of Availability of Virtual Simulation Media in Heat Transfer Material

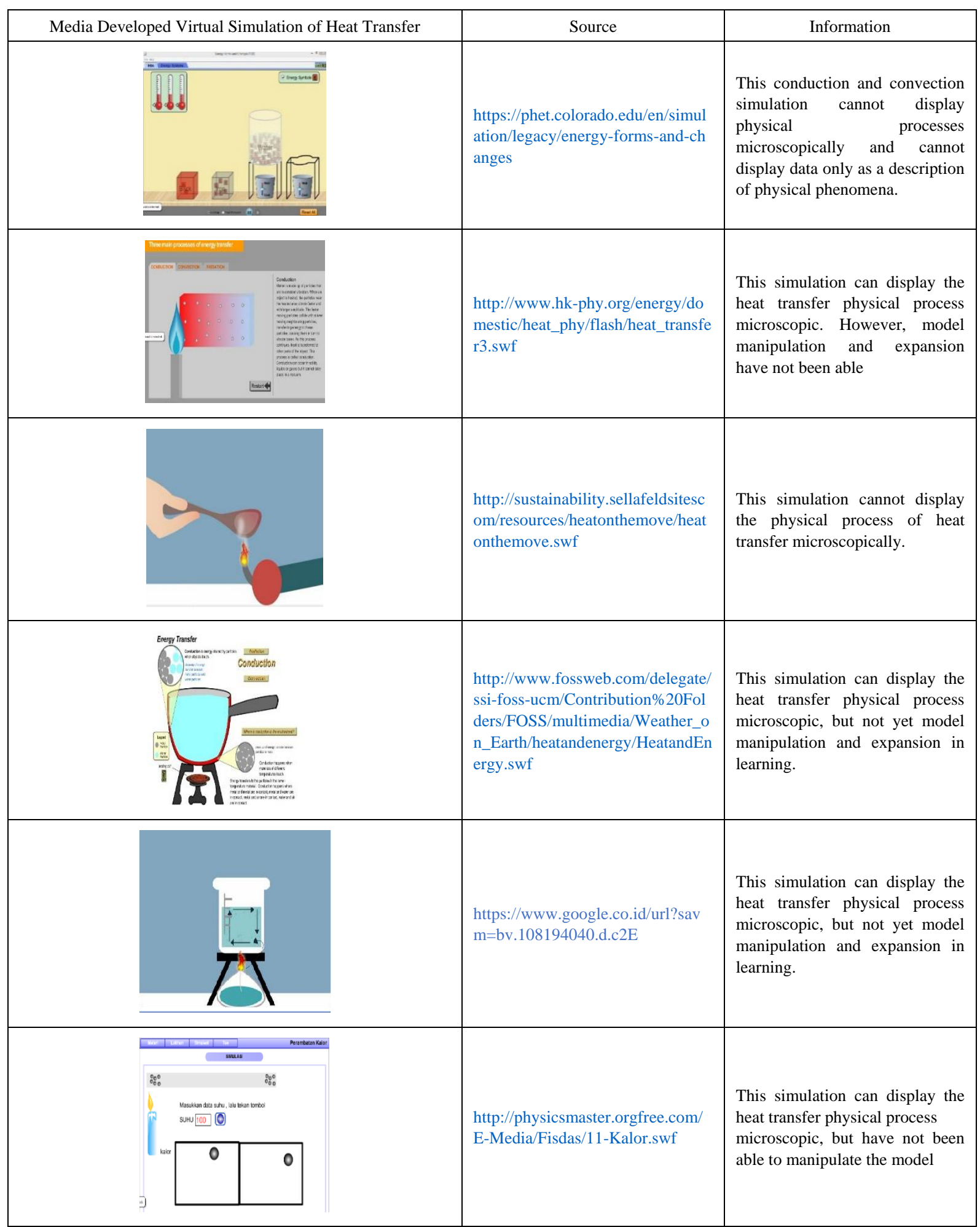


Based on Table 1, information was obtained that some simulation media on the concept of heat transfer still lacked and could not be said as a virtual laboratory simulation media. Therefore, a media development design was needed to get a product in the form of a virtual laboratory on the concept of heat transfer.

\section{Material and Method}

The research is a research and development $(\mathrm{R} \& \mathrm{D})$ that is oriented towards product development. In this study the product developed was in the form of Virtual Physics Laboratory (VPL) media on the concept of heat transfer. The design of this study refers to several Phases of the development research model. The development research model used is a 4-D model developed [13]. The 4-D development model consists of four main Phases, namely: Define, Design, Development and Disseminate. But in this study only carried out until the Development Phase, namely limited Test to students to find out students' responses to the media that have been developed. This development research was carried out in the 2018/2019 academic year, namely in the odd semester. The location of this research is in one of the teacher colleges in Indonesia. The subjects of the Test in the media development research Virtual Physics Laboratory (VPL) on the concept of heat transfer were students of 5 semesters of 60 people. This Phase was carried out to determine the students' responses to the VPL media developed. The object of this research is virtual lab-based learning media on the concept of heat transfer which can visualize macroscopic and microscopic phenomena. The instruments used to collect data in this study are Questionnaires compiled include three types according to the role and position of the respondents in this development research. The research instrument was in the form of a questionnaire compiled based on the grid that had been developed and arranged using a questionnaire scale.

\subsection{Media Evaluation Questionnaire for Virtual Physics Laboratory (VPL) in Media Experts}

The media assessment instrument was tested by media experts to measure the feasibility of VPL media that had been developed by researchers. Making instruments for data collection is based on the criteria for making good interactive multimedia by several experts and reference sources, including the opinions expressed [11]. The criteria for assessing multimedia-based computer-assisted teaching said to be good are as follows:

a. Ease of navigation. A program must be designed as simply as possible so language learners do not need to learn computers first.

b. Cognition is knowledge and presentation of information. This criterion is to assess the content of the program itself, whether the program has fulfilled the learning needs of the learner or not.

c. Media integration where the media must integrate language aspects and skills that must be learned. To attract the interest of learners the program must have an artistic appearance.

d. The program developed must provide the learning desired by the learner. The following is the aspect used to assess VPL media in Table 2.

Table 2. Questionnaire Aspect Media Expert

\begin{tabular}{|c|c|c|}
\hline No & Rated Aspect & Indicators of assessment aspects \\
\hline 1 & $\begin{array}{c}\text { Quality of } \\
\text { media design }\end{array}$ & $\begin{array}{ll}- & \text { Reliable } \\
\text { - } & \text { Maintainable }\end{array}$ \\
\hline 2 & $\begin{array}{c}\text { Media } \\
\text { interactivity }\end{array}$ & $\begin{array}{l}\text { - } \text { Communicative } \\
\text { Creative in the following ideas } \\
\text { pouring ideas Visual (layout } \\
\text { design, typography, color) } \\
\text { Mobile media (animation, movie, } \\
\text { interactive layout, navigation icon) }\end{array}$ \\
\hline
\end{tabular}

\subsection{Questionnaire for Media Evaluation of Virtual Physics Laboratory (VPL) in Content Experts}

The questionnaire is used to obtain data on the validity of VPL media products developed by researchers through testing by material experts. Following are the questionnaire grids in Table 3.

Table 3. Questionnaire Aspect for Content Experts

\begin{tabular}{|c|c|c|}
\hline No & Rated aspect & Indicators of assessment aspects \\
\hline 1 & Suitability of media with curriculum & $\begin{array}{l}\text { - } \quad \text { Material conformity with basic competencies } \\
\text { - } \quad \text { Material depth } \\
\text { - } \quad \text { The relevance of learning objectives with basic competencies } \\
\text { - } \quad \text { Ease to be understood, systematic, coherent, clear flow of logic } \\
\text { - } \quad \text { Completeness and quality of study aid concept } \\
\text { - } \quad \text { Compatibility of material with learning objectives } \\
\end{array}$ \\
\hline 2 & Motivation to learn & $\begin{array}{ll}\text { - } & \text { Presentation of material logically and systematically } \\
\text { - } & \text { Material presentation motivates learning } \\
\end{array}$ \\
\hline 3 & Language & $\begin{array}{ll}\text { - } & \text { Compliance with Indonesian language rules } \\
\text { - } & \text { Language effectiveness and efficiency } \\
\text { - } & \text { Completeness of information in the media }\end{array}$ \\
\hline
\end{tabular}




\subsection{Student Response Questionnaire}

Questionnaire for student responses is done to see student activities during the learning process with the multimedia learning model that is applied. Observations made are structured observations using a scale that is carried out on student learning activities during the teaching and learning process. The questionnaire grid to find out student responses to VPL media is shown in Table 4.

Table 4. Grid of Student Response Questionnaire

\begin{tabular}{|c|c|c|}
\hline No & Rated aspect & Indicators of assessment aspects \\
\hline 1 & Relevance & $\begin{array}{l}\text { - Update in using media } \\
\text { - } \quad \text { Can facilitate understanding the concept or material } \\
\text { - } \quad \text { Have content that is in accordance with student interests }\end{array}$ \\
\hline 2 & Confidence & $\begin{array}{l}\text { - } \quad \text { Can motivate learning } \\
\text { - } \quad \text { Encouraging feelings can learn the contents of learning material } \\
\text { - } \quad \text { Encourage curiosity in learning }\end{array}$ \\
\hline 3 & Satisfaction & $\begin{array}{l}\text { - } \quad \text { Feeling happy after learning the material } \\
\text { - } \quad \text { Ease in using media }\end{array}$ \\
\hline
\end{tabular}

\subsection{Research Procedural}

The research procedure is concrete and detailed steps, the elaboration of the chosen development model, namely the 4-D model. Therefore, according to the development model above, the procedure of this study is described in Figure 1.

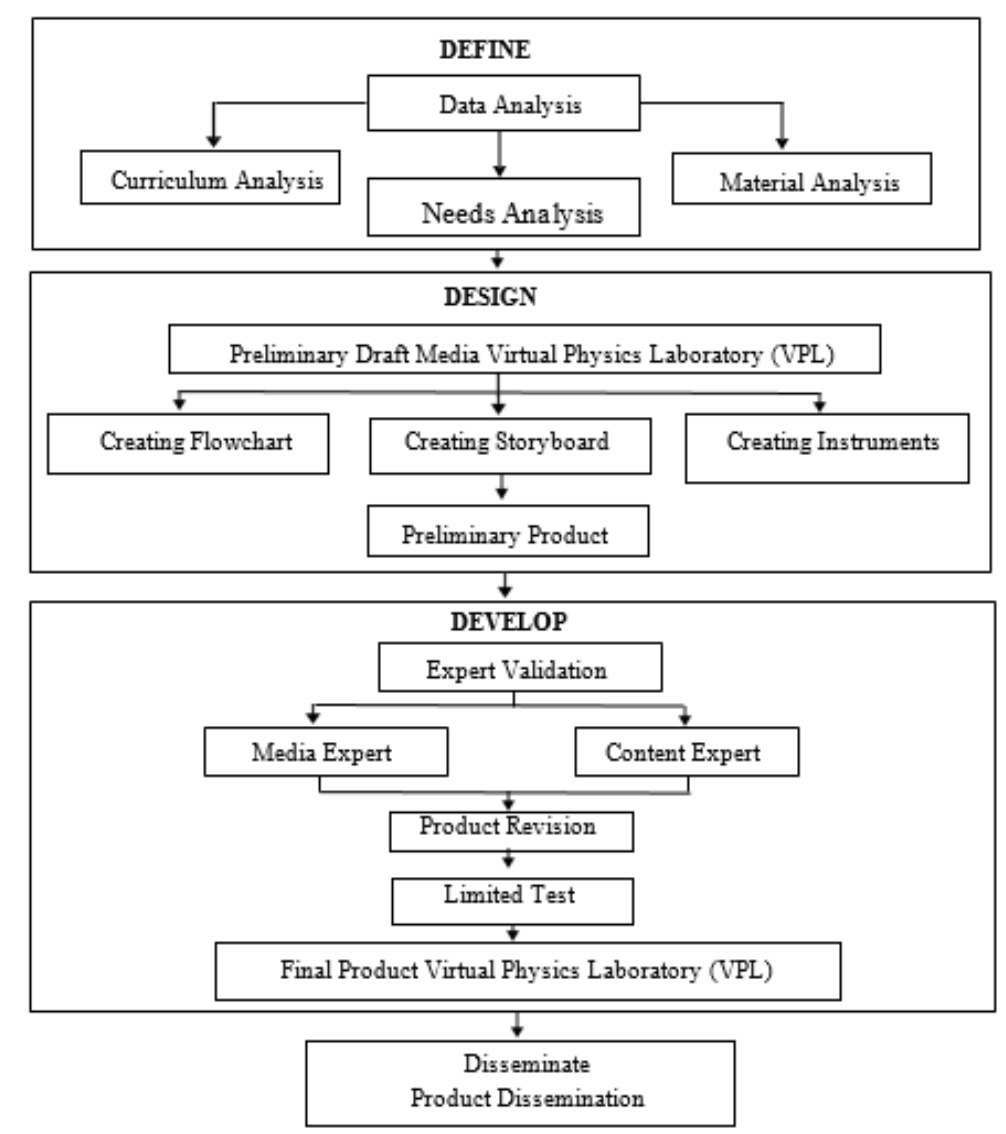

Figure 1. 4D Model 
Based on Figure 1, obtained information, the first step, defining is done by analyzing the curriculum done to gather information. Continued with a needs analysis carried out to see firsthand the state of the school, the potential it possesses, the availability of learning media facilities. The results of this field study concluded that physics subjects, especially heat transfer material, require media in learning. As well as material analysis is also called the learning design Phase. Learning design making contains elements (1) identification of competency standards; (2) analysis and determination of basic competencies; (3) formulation of indicators of success; (4) Making benchmark reference test items; (5) development of learning strategies; and (6) development and selection of learning media. The second step, the design of media development is carried out through the following steps: (1) Creating a schematic flowchart that is used as a navigation channel on the media developed. (2) Collecting supporting concept such as clip art images, animations, images, sounds, etc. that are used to create media. (3) Creating a storyboard that is used to make the correct frames. (4) Producing concept through computers using Adobe Flash based on storyboards and flowcharts. (5) Prepare instruments to assess the media developed by media, content and student experts. The third step, the evaluation phase of the VPL product consists of (1) validating the product through content experts and media experts, then proceeding with data analysis and product revisions. (2) Limited Test involving 30 students, followed by data analysis and product revisions. The fourth step, Disseminate is the final Phase in research and development where product development is promoted to be acceptable to users, either individuals, groups, or systems. This Phase of dissemination (disseminate) is the Phase of the use of devices that have been developed on a wider scale, for example in other classes, in other schools, by other teachers. The disseminate Phase in this research and development cannot be done due to time constraints. Therefore the research and development of Virtual laboratory Media according to the 4-D model only reaches the Phase of development or limited testing phase.

Data analysis using quantitative data analysis methods. Data is obtained from the results of questionnaires given to media experts, teacher and student content experts on the assessment of the media being developed. In addition, data is also taken from suggestions and criticisms regarding the quality of virtual multimedia products used in science learning.

\section{Results and Discussion}

The research on the development of virtual physics laboratory (VPL) was carried out based on the Research and Development ( $R$ \& D) procedure using a 4-D (defining, designing, developing and disseminating). In this study, it was only carried out until the development Phase, namely until the Test Phase was limited to students, due to time and cost limitations.

\subsection{Results of the Defining Phase}

This define phase is carried out by curriculum analysis conducted is to identify the basic competencies of the 2013 curriculum and understand the depth and breadth of competencies that must be developed, then describe and base competencies into several indicators. The basic competencies of matter of heat transfer are found in basic competencies. The analyzing the effect of heat and heat transfer which includes the thermal characteristics of a material, capacity, and heat conductivity in everyday life. Then from the basic competencies described into several indicators, namely (1) Explain how heat can move by conduction, convection and radiation, (2) Analyzing factors that affect the rate of heat transfer by conduction, convection, and radiation.

At the Phase of the virtual lab media needs analysis aims to determine the availability of media and the type of media used by the teacher when teaching, especially on heat transfer. Based on the results of interviews with physics teachers in several senior secondary schools, it was shown that there was still a low availability of physics learning media, especially in heat transfer concept.

The content analysis phase is done by adjusting the content with the basic competencies contained in the 2013 curriculum in Indonesia. The purpose of the content analysis is so that the content in the media is developed in accordance with the basic competencies contained in the heat transfer content. After the content analysis has been completed, then proceed to the next Phase, namely the design planning Phase.

\subsection{Results of the Design Phase}

Based on the findings at the defining Phase, media design was carried out to obtain VPL products on the concept of heat transfer. At the design Phase, the VPL media work system is designed in the form of a flowchart which then designs VPL media in the form of storyboards by adjusting the results of the defining Phase of analysis of curriculum, needs and content.

\subsection{Results of the Development Phase}

\subsubsection{Development of Media Virtual Physics Laboratory} (VPL)

The design of the media design of the Virtual Physics Laboratory (VPL) has been completed, the next Phase is the development of media. The initial Phase in the development of media is the process of making media that refers to flowcharts and storyboards that have been 
compiled at the design Phase. At the development Phase, it is done by perfecting the VPL media with the Adobe Flash application that has been developed by the researcher and has been improved based on the feasibility test and suggestions from the expert team. This Phase includes validation, revision, limited test and final product. The following is the display of VPL media that has been developed as shown in Table 5.

Table 5. Display of Virtual Physics Laboratory (VPL) Products

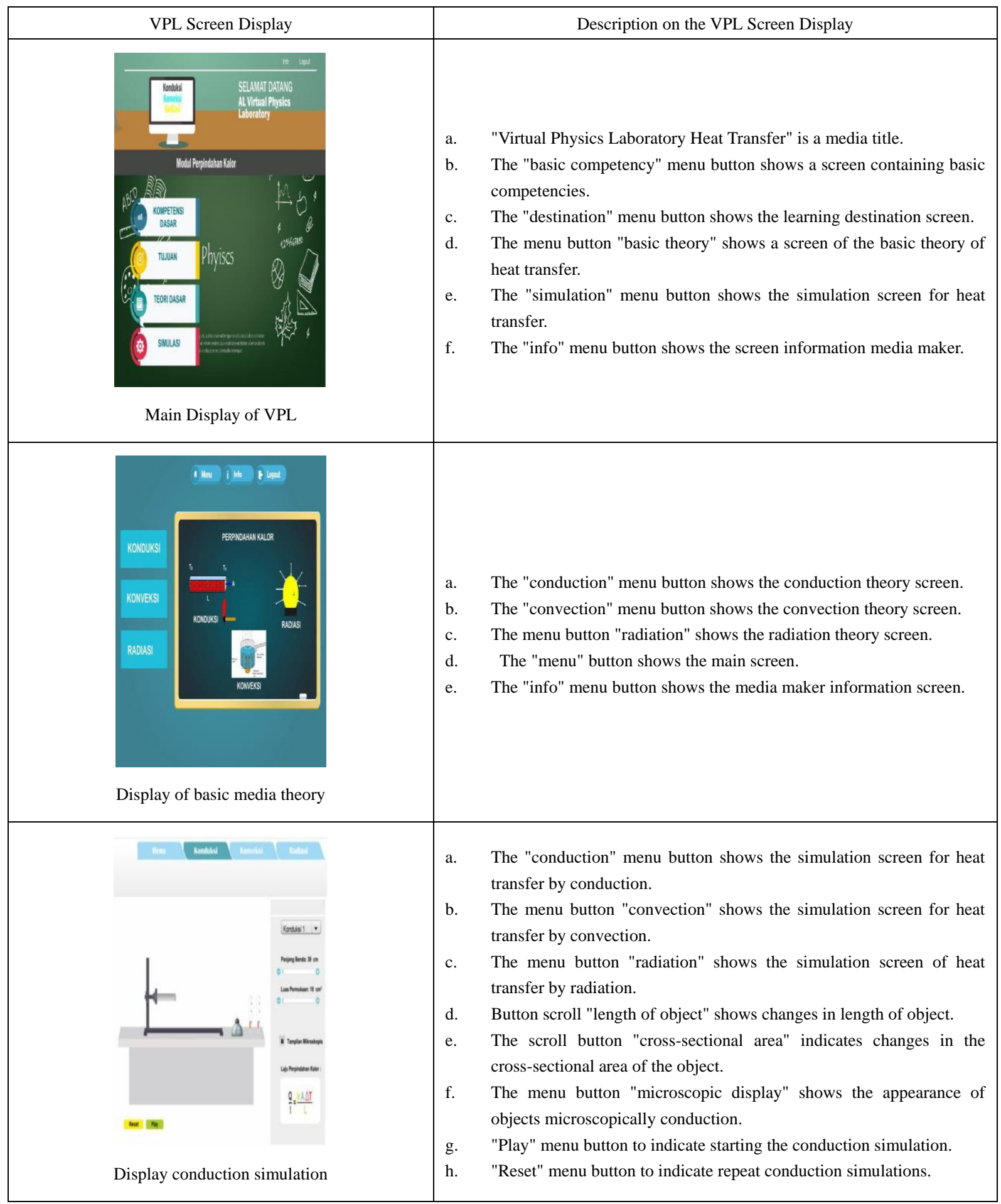




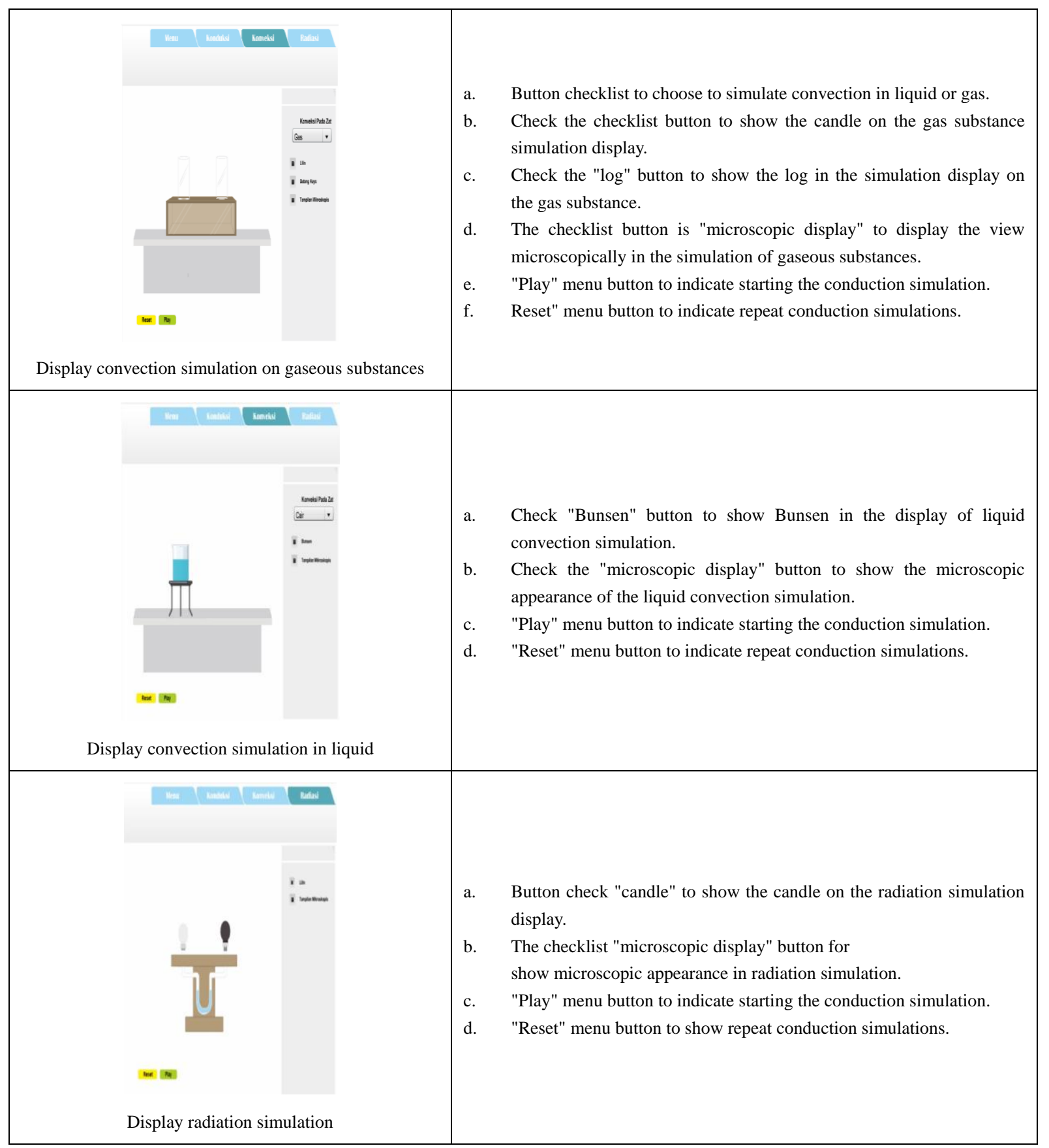

\subsection{Results of the Dissemination Phase}

\subsubsection{Media Evaluation Validation Virtual Physics Laboratory (VPL) by Experts}

Products that have been made are then consulted to be validated by media experts and physics content. This assessment aims to obtain input, suggestions, opinions, and evaluations of the media that have been made. Validation also aims to determine the feasibility of the media that has been produced, then tested on students to get the expected media development. In this validation Phase there are 4 validators consisting of 2 lecturers and 1 computer teacher as media experts and 1 lecturer as a content expert. The results of expert media research can be seen in each of the results of the validation recapitulation. In general, the results of the validation of aspects of media substance by media expert validators are some notes and suggestions that are used to improve the media.

From the overall validation that has been done by content experts and media experts, the results show that the VPL media that has been developed by researchers on average is very feasible with some improvements that must be made to improve the media. The results of media validation and content are shown in Table 6 and Table 7. 
Table 6. Results of VPL Simulation Evaluation Validation Media Experts

\begin{tabular}{|c|c|c|c|c|}
\hline \multirow{2}{*}{ No } & \multirow{2}{*}{ Assessment Aspect } & \multicolumn{3}{|c|}{ Rating Score } \\
\hline & & I & II & III \\
\hline \multicolumn{5}{|c|}{ Quality of VPL Design } \\
\hline 1 & $\begin{array}{l}\text { All navigation buttons are easy to find, attractive and function } \\
\text { good }\end{array}$ & 3 & 3 & 4 \\
\hline 2 & Fonts, font size, font color and letter layout are used & 4 & 4 & 4 \\
\hline 3 & Clarity of simulation, simulation size, and simulation layout & 4 & 3 & 4 \\
\hline 4 & Suitability simulation, simulation size and simulation layout & 4 & 4 & 3 \\
\hline 5 & Background of virtual laboratory simulation media & 3 & 3 & 4 \\
\hline 6 & Text and simulation used & 4 & 4 & 4 \\
\hline 7 & Display color composition used in laboratory virtual simulations & 4 & 4 & 4 \\
\hline \multicolumn{2}{|l|}{ Total } & 26 & 25 & 27 \\
\hline \multicolumn{2}{|c|}{ Average (percentage) } & \multicolumn{3}{|c|}{$26(92,85 \%)$} \\
\hline \multicolumn{2}{|l|}{ Category } & \multicolumn{3}{|c|}{ Very Good } \\
\hline \multicolumn{5}{|c|}{ Virtual Laboratory Media Simulation Interactivity } \\
\hline 1 & Ease of use of the navigation buttons & 4 & 3 & 4 \\
\hline 2 & Clarity of the link button in another page & 4 & 3 & 4 \\
\hline 3 & Ease of material structure to be understood & 3 & 3 & 4 \\
\hline 4 & The use of language is simple and clear & 4 & 2 & 4 \\
\hline \multicolumn{2}{|l|}{ Total } & 15 & 11 & 16 \\
\hline \multicolumn{2}{|c|}{ Average (percentage) } & \multicolumn{3}{|c|}{$14(87,5 \%)$} \\
\hline \multicolumn{2}{|l|}{ Category } & \multicolumn{3}{|c|}{ Very Good } \\
\hline
\end{tabular}

Table 7. Results of VPL Simulation Evaluation Validation Content Expert

\begin{tabular}{|c|c|c|c|c|}
\hline \multirow{2}{*}{ No } & \multirow{2}{*}{ Assessment Aspect } & \multicolumn{3}{|c|}{ Rating Score } \\
\hline & & $\mathrm{I}$ & II & III \\
\hline \multicolumn{5}{|c|}{ Conformity VPL with Curriculum: } \\
\hline 1 & Relationship between content and basic competencies & 5 & 4 & 5 \\
\hline 2 & Systematic presentation of content to achieve competence & 4 & 4 & 5 \\
\hline 3 & Achievement of practical learning / demonstration goals & 4 & 4 & 4 \\
\hline 4 & Consideration of the level of difficulty of the content & 4 & 5 & 4 \\
\hline 5 & Suitability between simulations is displayed with content / content & 3 & 4 & 5 \\
\hline 6 & Content relevance with visualization and simulation given & 4 & 5 & 4 \\
\hline \multicolumn{2}{|l|}{ Total } & 24 & 26 & 27 \\
\hline \multicolumn{2}{|c|}{ Average (percentage) } & \multicolumn{3}{|c|}{$25,67(85,56 \%)$} \\
\hline \multicolumn{2}{|l|}{ Category } & \multicolumn{3}{|c|}{ Very Good } \\
\hline \multicolumn{5}{|c|}{ Motivational Aspects of Learning: } \\
\hline 1 & $\begin{array}{l}\text { Simulation can develop logical thinking in understanding the } \\
\text { concept of heat transfer }\end{array}$ & 4 & 4 & 5 \\
\hline 2 & Simulation can motivate & 4 & 4 & 4 \\
\hline \multicolumn{2}{|l|}{ Total } & 8 & 8 & 9 \\
\hline \multicolumn{2}{|c|}{ Average (percentage) } & \multicolumn{3}{|c|}{$8,33(83,33)$} \\
\hline \multicolumn{2}{|l|}{ Category } & \multicolumn{3}{|c|}{ Very Good } \\
\hline \multicolumn{5}{|c|}{ Language aspects } \\
\hline 1 & The language used & 4 & 5 & 4 \\
\hline 2 & Complete sentence / information needed by the user & 3 & 4 & 5 \\
\hline 3 & Use of words according to Enhanced Spelling & 4 & 5 & 4 \\
\hline \multicolumn{2}{|l|}{ Total } & 11 & 14 & 13 \\
\hline \multicolumn{2}{|c|}{ Average (percentage) } & \multicolumn{3}{|c|}{$12(84,44 \%)$} \\
\hline \multicolumn{2}{|l|}{ Category } & \multicolumn{3}{|c|}{ Very Good } \\
\hline
\end{tabular}


Based on Tables 6 and Table 7, information is obtained that the VPL media that has been developed is in accordance with the content of heat transfer and with the appearance and interactivity of simulations that are already quite good. The media can already be used in research after improvements are made based on suggestions from experts, so that the media is truly suitable for use in physics learning, especially in heat transfer concept.

\subsubsection{Student Response to the Media Virtual Physics Laboratory (VPL)}

VPL media that has been validated by the expert team and revised based on the comments and suggestions of the expert team, then conducted a limited Test to students with a sample of 30 students. This Test was conducted to determine students' responses to media that have been made from aspects of media and concept. The following is the result of evaluating student responses to VPL media.

Table 8. Average Results of Assessment of Student Response to VPL Media in Limited Test

\begin{tabular}{|c|l|c|c|}
\hline \multirow{2}{*}{ No } & \multicolumn{1}{|c|}{ Statement } & \multicolumn{2}{|c|}{ Rating Result } \\
\cline { 2 - 4 } 1 & $\begin{array}{l}\text { Average } \\
\text { Criteria }\end{array}$ \\
\hline $\begin{array}{l}\text { new learning that is carried out at } \\
\text { our institution }\end{array}$ & $\begin{array}{l}\text { I feel that SV-FM is used to facilitate } \\
\text { me to understand physics concepts } \\
\text { that are not visible to the eye }\end{array}$ & 80,6 & $\begin{array}{c}\text { Very } \\
\text { Good }\end{array}$ \\
\hline 3 & $\begin{array}{l}\text { I feel that SV-FM which is used in } \\
\text { physics learning further increases } \\
\text { my motivation to learn changes in } \\
\text { matter. }\end{array}$ & 86 & $\begin{array}{c}\text { Very } \\
\text { Good }\end{array}$ \\
\hline 4 & $\begin{array}{l}\text { I feel that SV-FM used in learning is } \\
\text { interesting and easy to understand }\end{array}$ & 87,6 & $\begin{array}{c}\text { Very } \\
\text { Good }\end{array}$ \\
\hline 5 & $\begin{array}{l}\text { I feel SV-FM in physics learning can } \\
\text { help me understand the concept }\end{array}$ & 77,2 & Good \\
\hline 6 & $\begin{array}{l}\text { I feel SV-FM in learning physics can } \\
\text { help me understand microscopic } \\
\text { concepts of physics2 }\end{array}$ & 82,6 & $\begin{array}{c}\text { Very } \\
\text { Good }\end{array}$ \\
\hline 7 & $\begin{array}{l}\text { I feel that SV-FM that is used can } \\
\text { make it easier for me to study } \\
\text { physics }\end{array}$ & 86,8 & $\begin{array}{c}\text { Very } \\
\text { Good }\end{array}$ \\
\hline 8 & $\begin{array}{l}\text { I feel happy to learn using SV-FM } \\
\text { and hope that it can be used on other } \\
\text { subjects }\end{array}$ & 86,6 & $\begin{array}{c}\text { Very } \\
\text { Good }\end{array}$ \\
\hline Score NP (\%) & $86 \%$ \\
\hline Category & \multicolumn{2}{|c|}{ Very Good } \\
\hline
\end{tabular}

Based on Table 8. The information is obtained that students' responses to VPL media can be categorized very well. It can be concluded that the learning media developed in the form of virtual laboratory media can visualize the process of heat transfer that can be used in physics learning.

\subsubsection{Characteristics of the Media Virtual Physics Laboratory (VPL)}

VPL media design on heat transfer content that has been validated and revised based on suggestions and notes from experts contains the initial display, main view, basic theory display, basic competency schedule, display of learning objectives and simulation display. The initial appearance of the media is as shown in the following image.

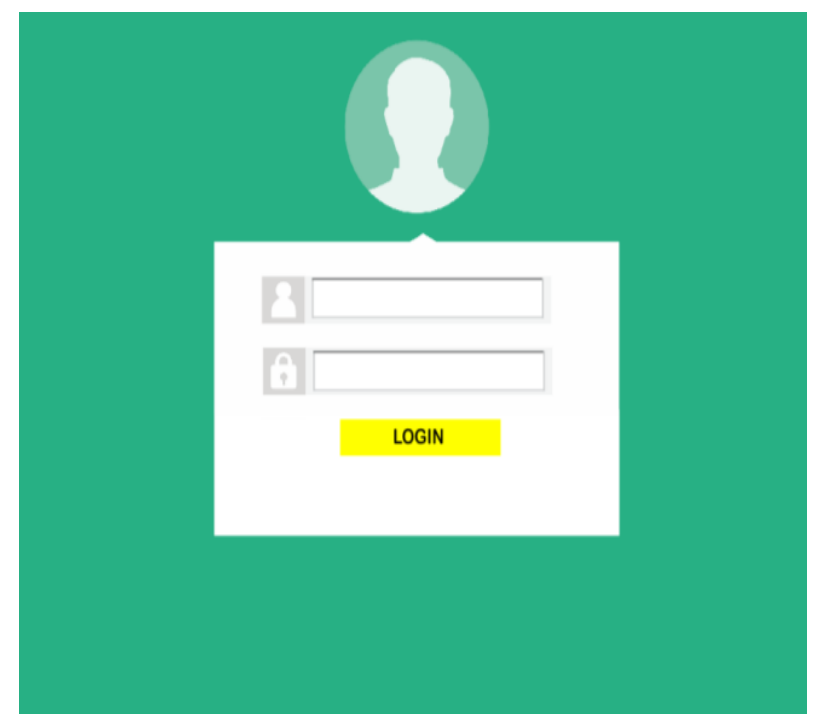

Figure 2. Initial Display of VPL

The initial display there is a column "username" and "password" and a "login" button. In this initial view, the user must enter the username and password data from the builder to $\log$ in and enter the main media menu.

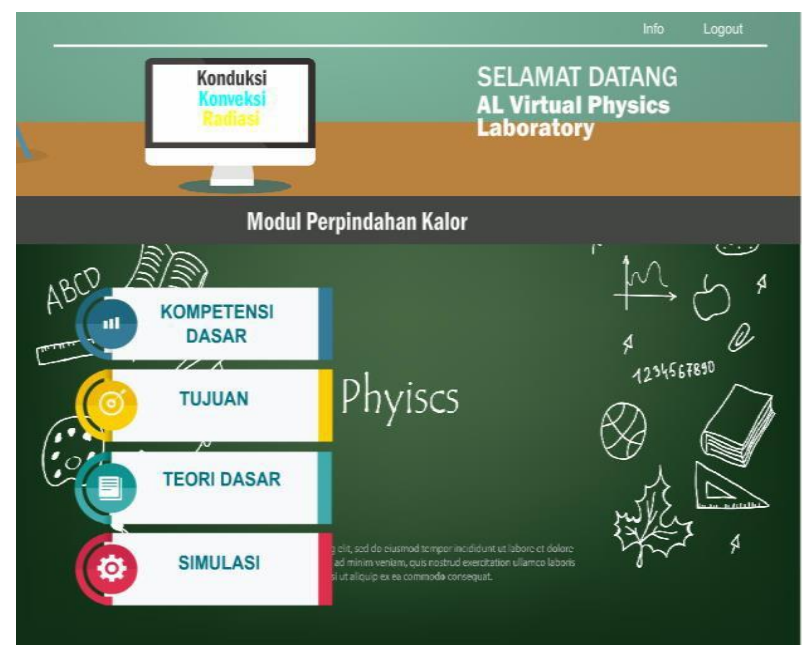

Figure 3. Display of VPL Main Menu

In the main menu display, there is a button "basic competencies, goals, basic theory, simulation, logout and info". The button "info serves to display profile information for media developers. The "logout" button functions to exit the media. The "basic competency" button serves to display basic competencies on the subject of heat transfer. "Destination" button to display the learning objectives. Button "basic theory" to display heat transfer concept (conduction, convection, and radiation). 
"Basic theory" button to display the basic theory of heat transfer by conduction, convection, and radiation. In this display there are buttons for conduction, convection and radiation, each of which functions to get to the theory that corresponds to the button. Following is the basic view of the theory.

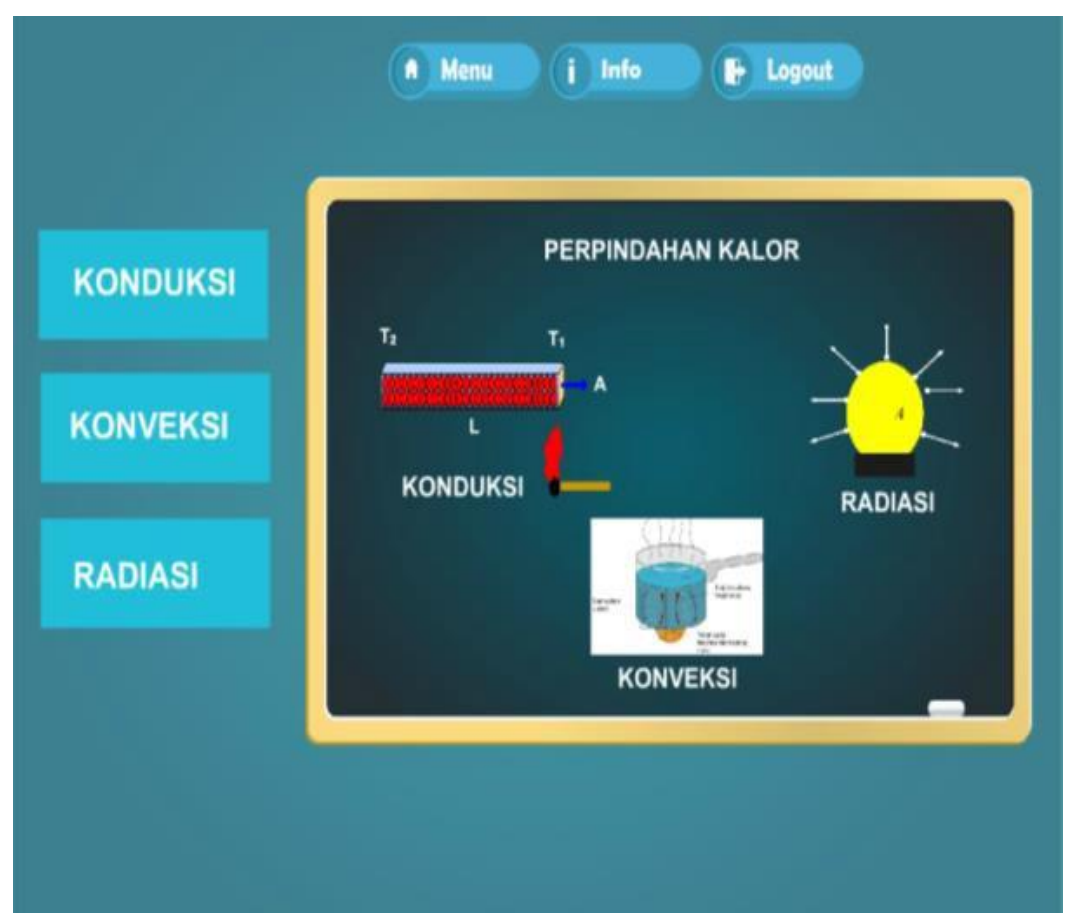

Figure 4. Display of the Basic Theory Menu

"Simulation" button to display a heat transfer simulation as shown in the following figure.

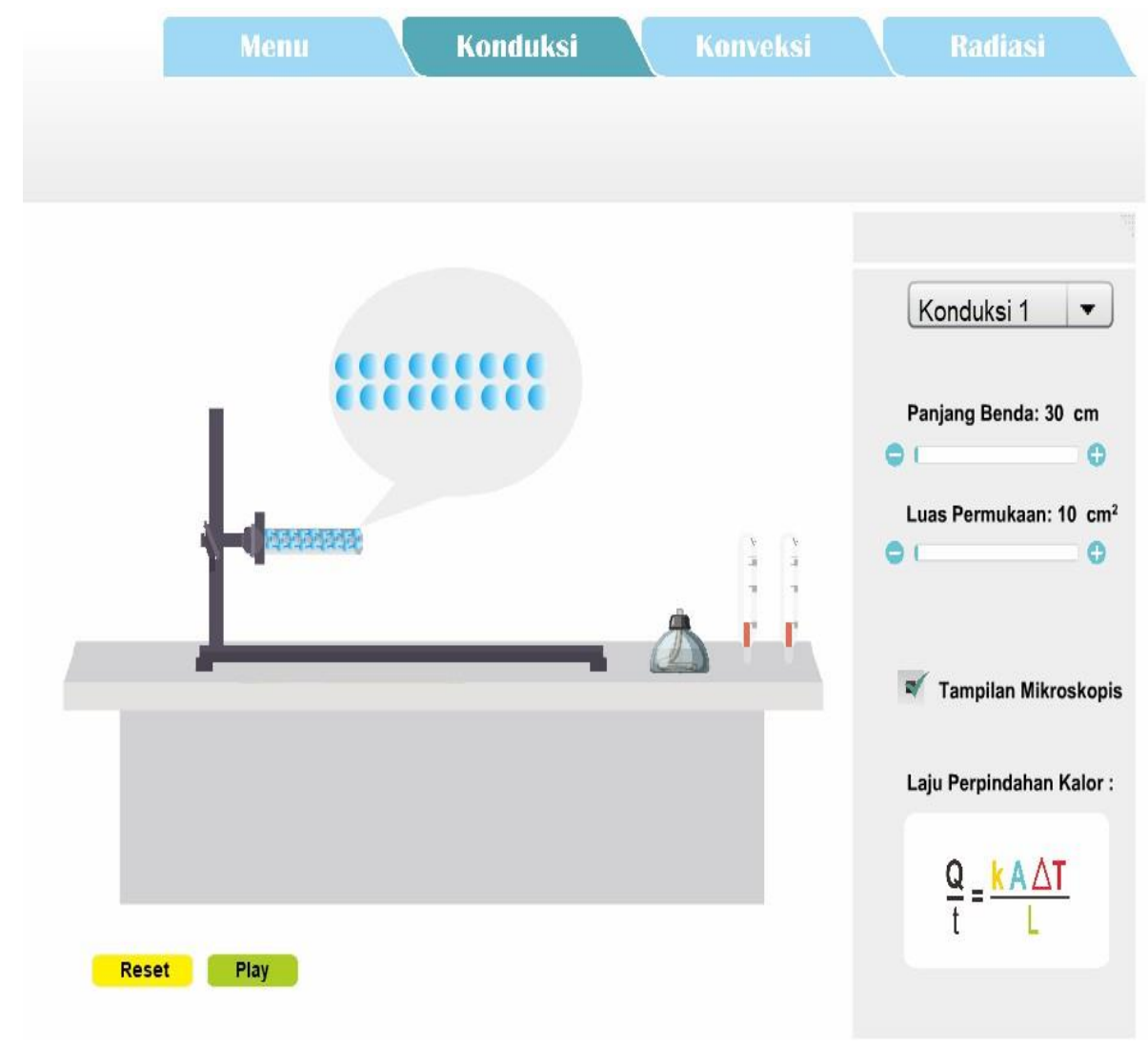

Figure 5. Conduction Simulation 
The demonstration or conduction experiment simulation display there is one object that is clamped by a buffer and placed on a table, this rod can be changed in length and cross-sectional area. There are two thermometers that are used as indicators of temperature rise at both ends of the rod, as well as Bunsen as a heat source. The form of simulation that can be done in this view is a simulation of heat transfer by conduction at one end of the heated rod using Bunsen. In this simulation can be shown the microscopic process of heat transfer by conduction. Heat transfer can be observed with an increase in temperature at the end of the Bunsen that does not experience direct contact with the heat source using a thermometer. Heat transfer can be observed with solid constituent particles that experience direct contact with heat sources which vibrate more strongly than particles that do not experience direct contact. The greater the vibration, the greater the kinetic energy. The large kinetic energy causes the particles nearby to vibrate to be stronger than before, then onwards to the other constituent particles. This can be seen by changing the color gradation of particles from blue (indicating lower temperatures) to red (indicating higher temperatures).

The simulation it can also show variable relations of object length and cross-sectional area of objects with heat transfer rate. The length and cross-sectional area of the Bunsen can be changed to show the relationship that the larger the Bunsen length, the smaller the heat transfer rate as well as possible, whereas if the cross-sectional area is changed to be enlarged, the heat transfer rate becomes even greater. This can be shown from the process of heat transfer in solid constituent particles, temperature rise in the thermometer and in the heat transfer rate equation. At the display of the heat transfer rate there is an equation that can explain the relationship between the length and cross-sectional area of the Bunsen.

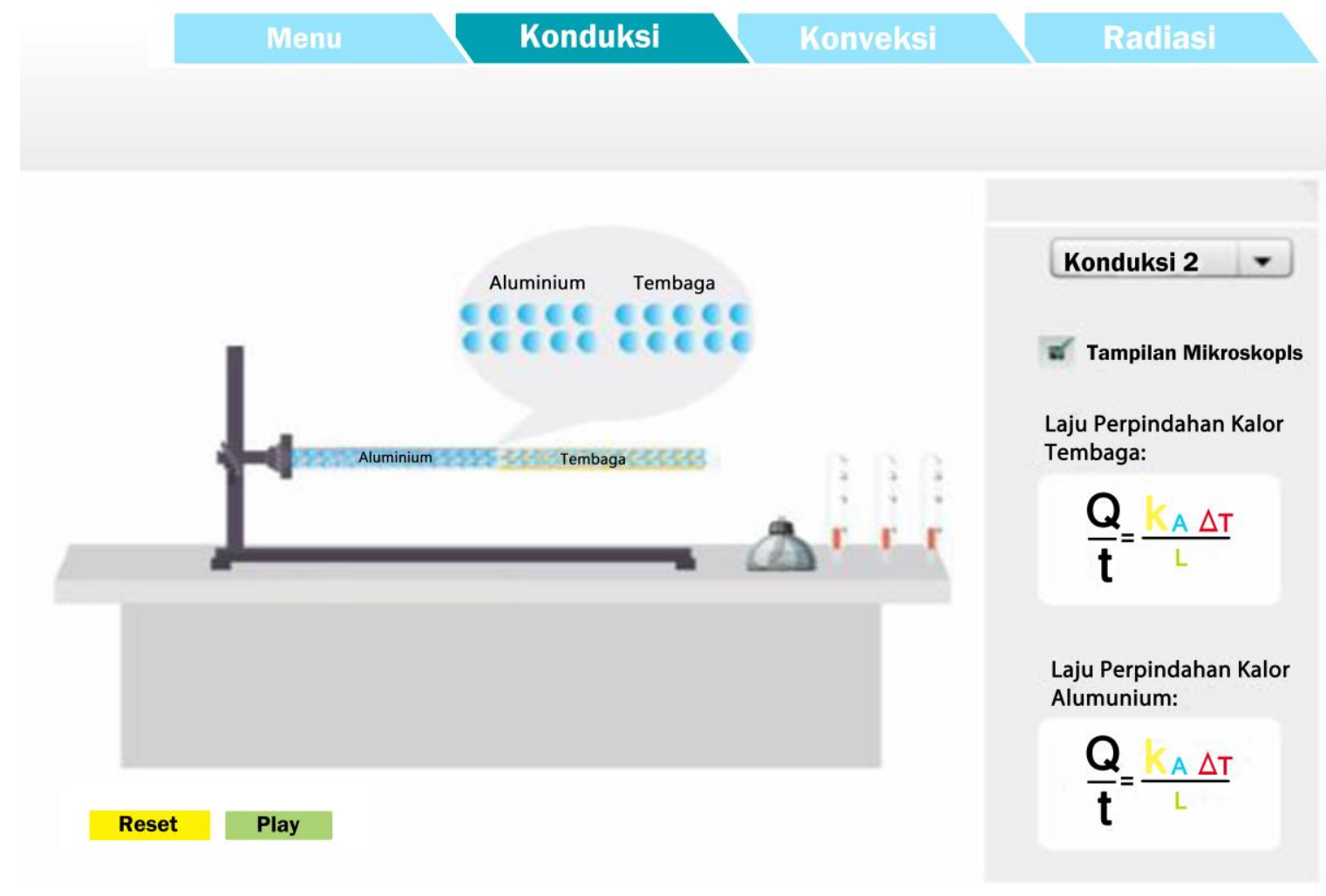

Figure 6. Conduction Simulation on Two Bunsen

The conduction simulations on one rod, a simulation of conduction heat transfer can also be carried out between two objects. This simulation serves to show the factor of thermal conductivity of a content can affect the rate of heat transfer. In this simulation, the heat transfer of the object's rod can be observed with the temperature rise in the thermometer on each end of the aluminum and copper rods. In addition, microscopically heat transfer is shown by aluminum and copper constituents. The heat transfer rate of copper will be greater than the heat transfer rate of aluminum because the thermal conductivity of copper is greater than that of aluminum. This is indicated by particle vibrations and color gradations of the bonding particles making up each content and the heat transfer rate equation. Meanwhile, in each simulation display the heat transfer process is a menu bar at the top which shows a demonstration simulation / experiment in the heat transfer process that is currently active and another menu button that directs the user to the desired simulation. In addition there is a "menu" button that functions to return to the main menu appearance.

When a user clicks the convection button on the menu bar, the user will be directed to the demonstration / convection experiment display. In the initial display, the convection simulation screen has a box on top of which there is a chimney-shaped hole in the right and left ends respectively. 


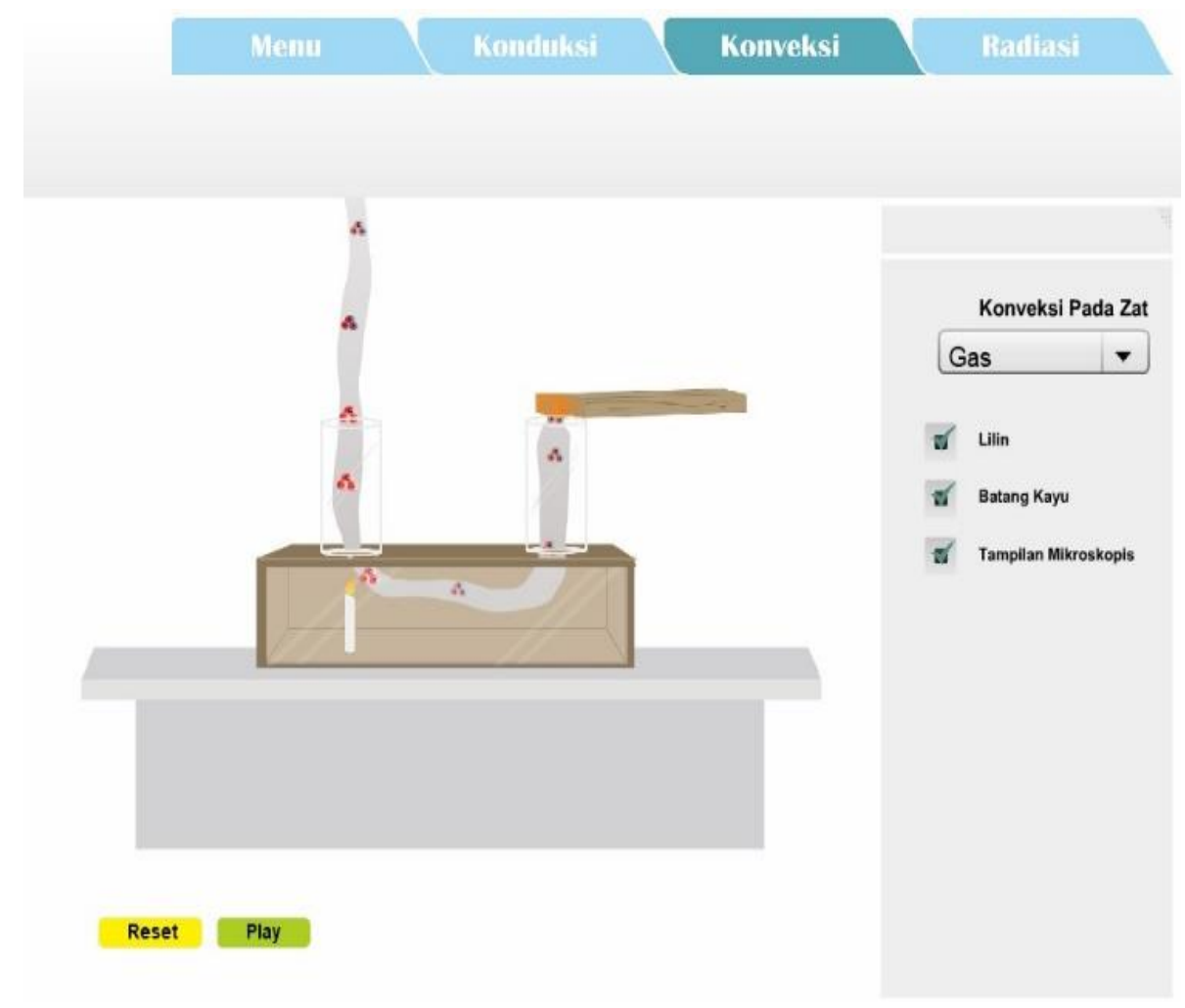

Figure 7. Simulation of Convection on Gas

The form of simulation that can be done on this screen is a simulation of heat transfer by convection in the gas. Convection in gas, for example, occurs when hot air rises and cooler air drops. This can be observed through this simulation. When the candle is lit it will make the air around the candle will be higher than before so that it moves upward through the carriage closest to the candle, when the air around the candle rises, the place is replaced by cooler air that enters the other chimney. This situation continues to occur so that there is air flow. This can be observed with the movement of smoke from wood that has been burned and placed at one end of the chimney and microscopic view.

In convection simulation not only can you display convection simulations on gaseous substances, but can also display demonstration / experimental simulations on liquids. In the initial display of the simulation screen, the heat transfer by convection in the liquid contains a container containing water below which Bunsen as a heat source is placed on the table.

The form of simulation that can be done on this screen is a convection simulation when cooking water. In this simulation it can show the microscopic process of heat transfer by convection. Heat transfer can be observed with particles below which are closer to the heat source having greater kinetic energy, this can be seen from the movement of particles and changes in color coloration of the constituent particles of water. In this section the water will expand so that the density of the water becomes smaller than the density of the water that is still cooler above it, consequently this water molecule will move up. The part of the water that experiences expansion will move up because the density is smaller, the water molecule that is beside the left and right will try to fill the position of the rising part of the water.

When the user clicks on the radiation button on the menu bar, the user will be directed to the radiation experiment simulation screen. At the beginning of the radiation simulation screen, there are props, namely a thermo scope that is used to observe the process of heat transfer by radiation. In this thermos cope there are dark, light-colored lampshades which are both connected with a (U) shaped pipe filled with alcohols that have a low density. In the middle, the candle is placed as a heat source which can emit thermal radiation on the two glass lamps. 


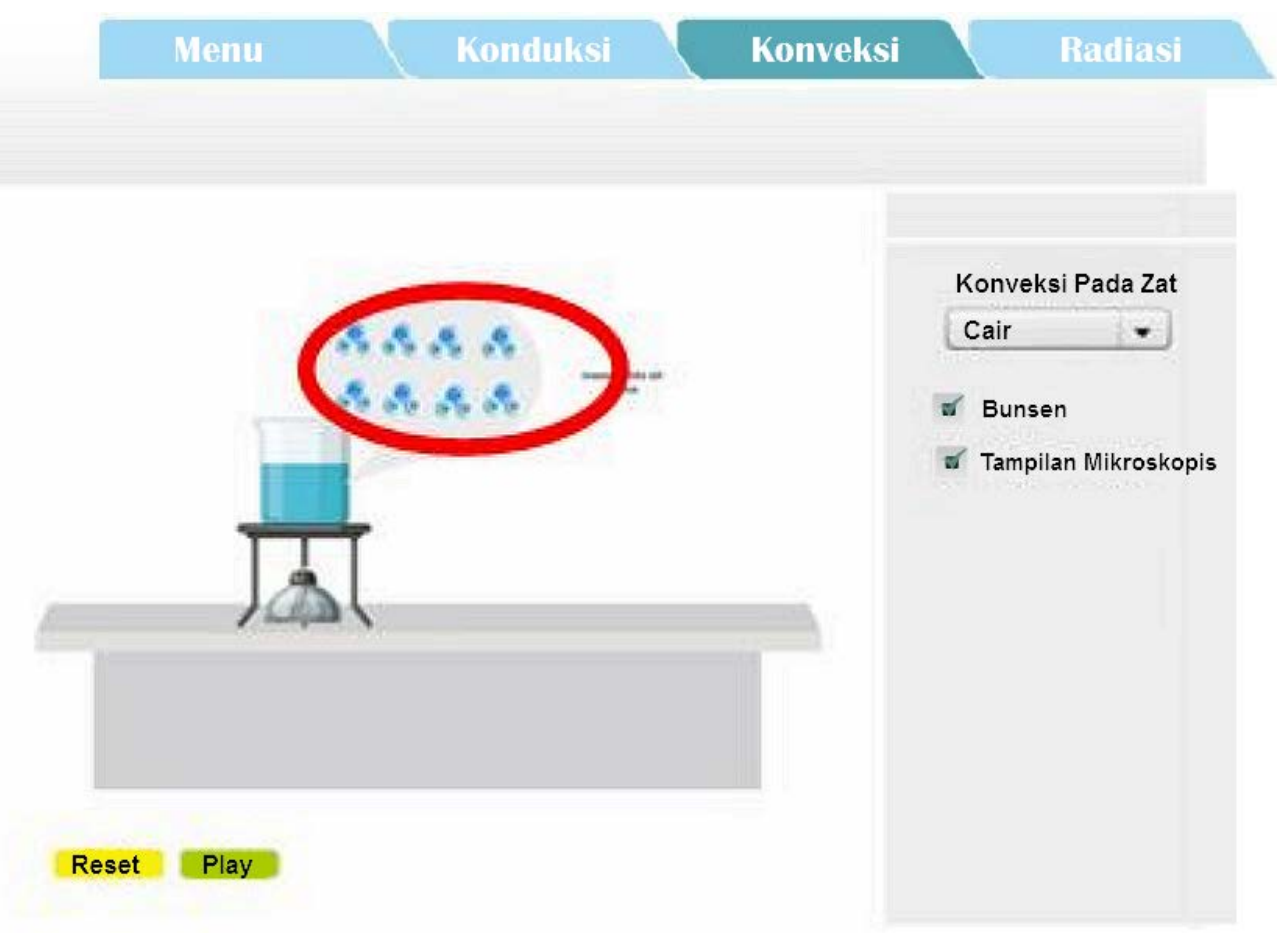

Figure 8. Convection Simulation on Liquid Substances

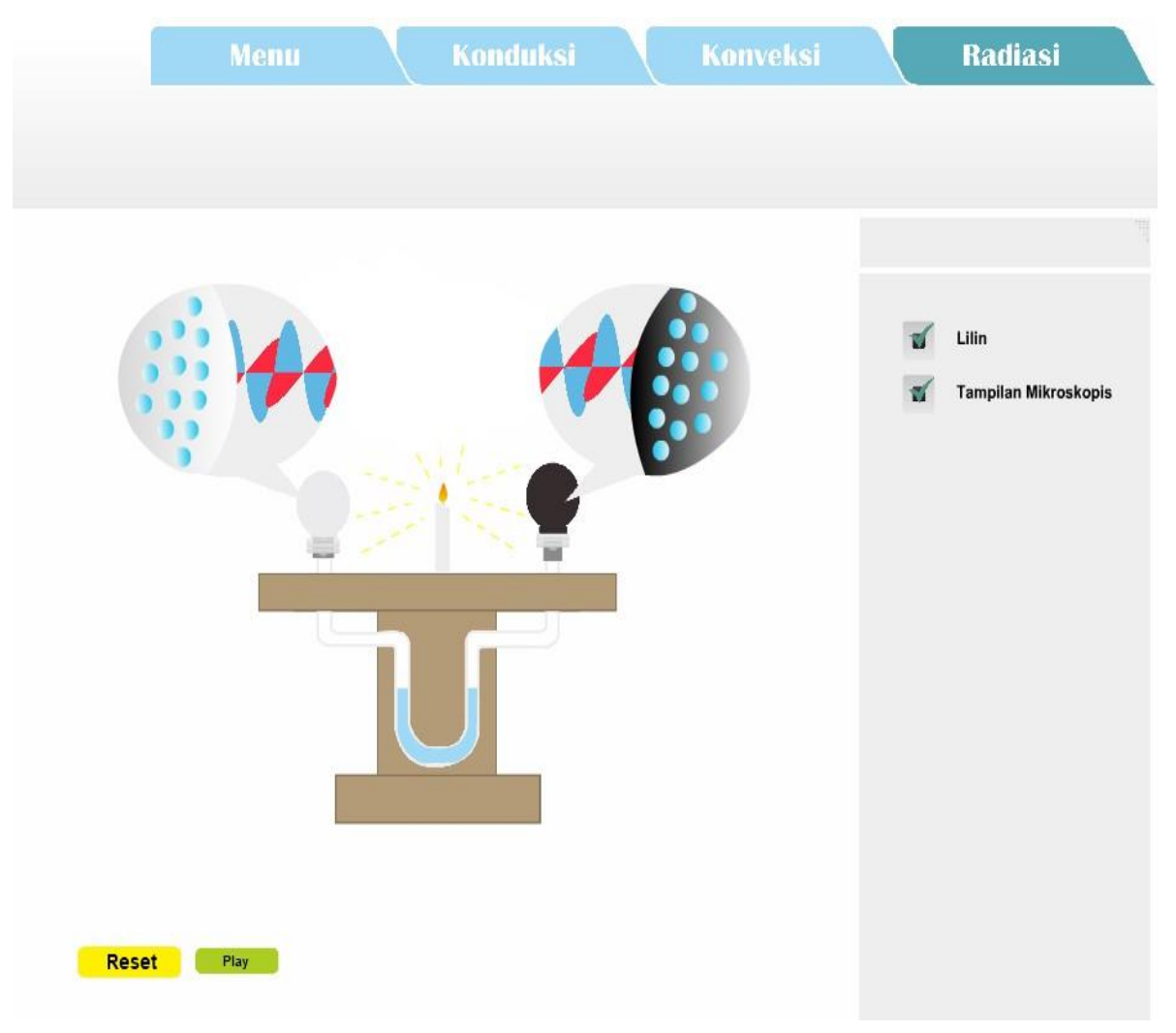

Figure 9. Radiation Simulation

The form of simulation that can be done on this simulation screen is radiation simulation through wax as a heat source that emits thermal radiation at two different colored lights which are connected by a pipe (U) filled with alcohol as an indicator of temperature changes in both lights. In this simulation can be shown the microscopic process of heat transfer by radiation. Heat transfer can be observed with the rise or fall of alcohol as a temperature indicator on both lights. The black lights will absorb more heat than the white lights, this will cause the air to be 
blackened to experience a faster temperature change which will make the movement of the air molecules faster and will result in higher air pressure in the black lights which will encourage alcohol go to the white light pipe section, so that the alcohol will be seen down next to the black light pipe section and will be seen rising beside the white light pipe section.

In addition, microscopic black light constituents that have direct contact with thermal radiation sources have greater kinetic energy than before because black lights absorb more heat from the emission of thermal radiation compared to white lights which absorb less heat and reflect more light. Thermal radiation, this is because black lights have greater emissivity than white lights. This phenomenon can be shown or visualized by the movement of the light molecules and changes in the color gradation of the particles.

\subsubsection{Feasibility of the Media Virtual Physics Laboratory (VPL)}

The description of the results of previous studies, the media Virtual Physics Laboratory (VPL) that has been developed has been assessed by experts. The evaluation validation test is carried out by 4 experts consisting of media experts and content experts. Based on the results of VPL media validation assessment, it obtained an average value of $84.17 \%$ and was declared very well. The results of the average assessment of the feasibility of each expert on VPL media are shown in Figure 10.

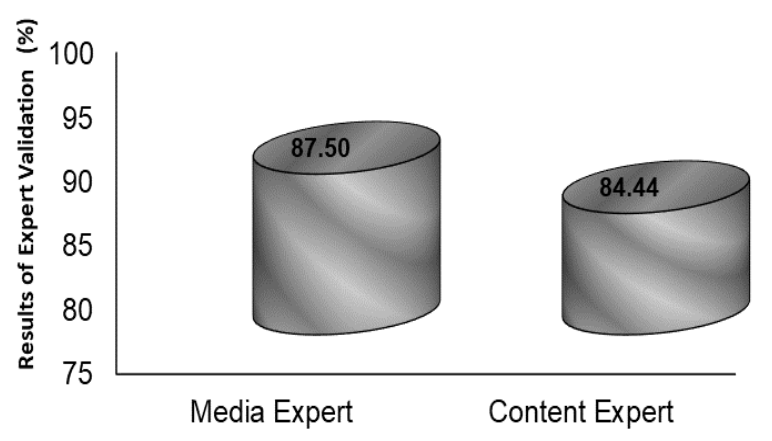

Figure 10. Percentage of VPL Evaluation Validation Media Expert and Content Expert

The Media Virtual Physics Laboratory (VPL), which has been validated by a team of experts, was revised based on suggestions and notes from the expert team, then limited Test were conducted. The average of percentage of VPL evaluation validation expert is $85,97 \%$ the was conducted in the department of physics education.

\section{Conclusions}

Based on the results of the research and discussion, it can be concluded that the Media virtual physics laboratory (VPL) which was developed as a tool in physics learning, especially in heat transfer concept has the characteristics of (1) displaying both macroscopic and microscopic phenomena. (2) Some simulations can be changed so that users like to do real labs. (3) Equipped with navigation buttons so that they are easy to use (user friendly) and attractive and informative. The results of VPL media expert obtained an average value of $87,50 \%$ with a very good category, results of VPL content expert obtained an average value of $84.44 \%$ with a very good category, and the results of Test were limited to students obtaining an average score of $86 \%$ with a very good category. Based on the results of the study, it can be concluded that the learning media developed in the form of virtual laboratory media can visualize the process of microscopic heat transfer that can be used in physics learning.

Based on the results of the research and discussion that have been conducted, the researcher can suggest the following (1) media that has been developed by the researcher, can be continued by other researchers to be implemented into the school and used as a means for schools to support teaching and learning activities. (2) For further research it can be considered the development of VPL on the concept of heat transfer, more variables are developed so that practicum activities will be virtualized better.

\section{Declaration of Conflicting Interests}

The authors declared no potential conflicts of interest with respect to the research, authorship, and/or publication of this article.

\section{Funding}

The researchh was funded by research grant research at the Ministry of Research, Technology and Higher Education 2019.

\section{REFRENCES}

[1] Arista, F. S., \& Kuswanto, H. (2018). Virtual Physics Laboratory Application Based on the Android Smartphone to Improve Learning Independence and Conceptual Understanding. International Journal of Instruction, vol 11(1), 1-16.

[2] Ballu, A., Yan, X., Blanchard, A., Clet, T., Mouton, S., \& Niandou, H. (2016). Virtual Metrology Laboratory for e-Learning. Procedia CIRP, 43, 148-153.

[3] Bromme, R., \& Beelmann, A. (2016). Transfer Entails Communication: The Public Understanding of (Social) Science as a Stage and a Play for Implementing Evidence-Based Prevention Knowledge and Programs. Prevention Science, 19(3), 347-357. 
[4] Darman D. R., F. C. Wibowo, A. Suhandi, W. Setiawan, H. Abizar, S. Nurhaji, L. Nulhakim and A. Istiandaru. (2019). Virtual media simulation technology on mathematical representation of sound waves. J. Phys.: Conf. Ser. 1188 012092

[5] Engelou, F., \& Kotsis., K. (2018): Real vs virtual physicsexperiments: comparison of learning outcomes among fifth grade primary school students.A case on the concept of frictional force, International Journal of Science Education. 41 (3), 330-348.

[6] Ghoniem, R. M., Abas, H. A., \& Bdair, H. A. (2018). A novel intelligent object-oriented three-dimensional simulation system for Physics experimentation. Applied Computing and Informatics. 1: 1-11.

[7] Gunn, T., Jones, L., Bridge, P., Rowntree, P., \& Nissen, L. (2017). The use of virtual reality simulation to improve technical skill in the undergraduate medical imaging student. Interactive Learning Environments, 26(5), 613620.

[8] Nelson, K. G., McKenna, A. F., Brem, S. K., Hilpert, J., Husman, J., \& Pettinato, E. (2017). Students' Misconceptions about Semiconductors and Use of Knowledge in Simulations. Journal of Engineering Education, 106(2), 218-244.

[9] Olympiou, G., \& Zacharia, Z. C. (2018). Examining Students' Actions While Experimenting with a Blended Combination of Physical Manipulatives and Virtual Manipulatives in Physics. Research on e-Learning and ICT in Education, 257-278.

[10] Pérez-Espigares, C., Carollo, F., Garrahan, J. P., \& Hurtado, P. I. (2018). Dynamical criticality in open systems: Nonperturbative physics, microscopic origin, and direct observation. Physical Review E, 98(6).

[11] Pirker, J., Lesjak, I., \& Gütl, C. (2017). An Educational Physics Laboratory in Mobile Versus Room Scale Virtual Reality - A Comparative Study. International Journal of Online Engineering, 13(08), 106.

[12] Potkonjak, V., Gardner, M., Callaghan, V., Mattila, P., Guetl, C., Petrović, V. M., \& Jovanović, K. (2016). Virtual laboratories for education in science, technology, and engineering: A review. Computers \& Education, 95, 309327.

[13] Rahmadani, A. F., Hidayat, H., \& Syahmaidi, E. (2018). Design of Electronic Elementary Material Learning Module on Vocational Higher Education. International Journal of Scientific Research and Management, 6(01), EL-2018

[14] Raissi, M., \& Karniadakis, G. E. (2018). Hidden physics models: Machine learning of nonlinear partial differential equations. Journal of Computational Physics, 357, 125141.

[15] Valdehita, R. E., Medina-Merodio, J.-A., \& Plata, R. B. (2019). Student acceptance of virtual laboratory and practical work: An extension of the technology acceptance model. Computers \& Education. 135: 1-14.

[16] Wästberg S., B., Eriksson, T., Karlsson, G., Sunnerstam, M., Axelsson, M., \& Billger, M. (2019). Design considerations for virtual laboratories: A comparative study of two virtual laboratories for learning about gas solubility and colour appearance. Education and Information Technologies. 24 (3), 2059-2080.

[17] Wen, C.-T., Chang, C.-J., Chang, M.-H., Fan Chiang, S.-H., Liu, C.-C., Hwang, F.-K., \& Tsai, C.-C. (2018). The learning analytics of model-based learning facilitated by a problem-solving simulation game. Instructional Science. 46 (6): 847-867

[18] Wibowo, F.C., et al. (2017). Effectiveness of Dry Cell Microscopic Simulation (DCMS) to Promote Conceptual Understanding about Battery. Journal of Phyiscs: Conference. 877 (1), 012009.

[19] Wibowo, F.C., et al. (2017). Effectiveness of Microscopic Virtual Simulation (MVS) for Conceptualizing Students' Conceptions on Phase Transitions. Advanced Science Letters. 23 (2), 839-843.

[20] Wibowo, F. C., et al. (2017). Virtual Microscopic Simulati on (VMS) to Promote Students' Conceptual Change: A Case Study of Heat Transfer. Asia-Pacific Forum on Science Learning \& Teaching. 18 (2), 1-32.

[21] Falode O. Caleb. (2018). Pre-service Teachers' Perceived Ease of Use, Perceived Usefulness, Attitude and Intentions Towards Virtual Laboratory Package Utilization in Teaching and Learning of Physics. Malaysian Online Journal of Educational Technology. 6(3): 63-72.

[22] Duban N. Bülent A. Asl1 Y. (2019). Classroom Teachers' Opinions on Science Laboratory Practices. Universal Journal of Educational Research 7(3): 772-7.

[23] D R Darman, F C Wibowo, A Suhandi, WSetiawan, H Abizar, S Nurhaji, L Nulhakim and A Istiandaru. (2019). Virtual media simulation technology on mathematical representation of sound waves. IOP Conf. Series: Journal of Physics: Conf. Series 1188012092 